\title{
Total Quality Management
}

\author{
Jarrod Richards \\ School of Business, Fairmont State University, 1201 Locust Avenue, Fairmont, WV \\ 26554, USA \\ E-mail: Jarrod.P.Richards@gmail.com
}

Received: October 25, 2012 Accepted: October 29, 2012 Published: December 31, 2012

doi:10.5296/bms.v3i2.2910 URL: http://dx.doi.org/10.5296/bms.v3i2.2910

\begin{abstract}
Total Quality Management is a management theory that managers and companies talk about but know very little to implement. This paper takes a strong look at the history of Total Quality Management (TQM) from its origins to current successes in implementation. We look at how TQM has changed governments to increasing productivity and profits within organizations. This paper also looks into the strategic role that a company could take in order to see change to quality first. This requires a structure change in the organization from CEO down to front line workers. The practice of TQM can grow a company to have a sustainable competitive advantage in local and international markets.
\end{abstract}

Keywords: Total Quality Management, TQM, Strategic management, Management, Toyota, General motors 
1. Introduction

W. Edwards Deming said that "ultimately, management's job is to hone the entire system so that it is capable of making the leap from continual improvement to continual innovation" (Perdomo-Ortiz, Gonza' lez-Benito, \& Galende, 2009, p. 5088). Doing business in today's market can be highly competitive. The goal for any company should be to obtain a sustainable competitive advantage (Surendran, 2010, p. 57). Many companies do this in different ways. One of the more popular theories in the world of business today is Total Quality Management (TQM). TQM can be defined as an integrative approach to management that supports the attainment of customer satisfaction through a wide variety of tools and techniques that the end result is higher quality of goods and services (Bateman $\&$ Snell, 2007, p. 302). Another shorter definition to TQM is a comprehensive approach to achieving business excellence (P \& Srinivasan, 2010, p. 8) . After looking at both definitions one could easily ascertain that TQM is not an easy task. Every time a company starts on the TQM strategy a competitor then goes improves their strategy. This is what makes business in the free market great. This paper is going to discuss a more detailed look on what TQM is and how it affects both the company's product as well as improving the supply chain of a company.

\section{Total Quality Management}

Total Quality Management has given business a new avenue on to improve products and services. Another name for TQM is continuous improvement which means a commitment to constantly improving the quality of a product (Decenzo, Robbins, \& Verhulst, 2010, p. 18). This kind of quality management requires the company to always check to make sure that product or service is at the standard that both the company and customer wants is maintained. Unlike the older style of quality check where a quality department would monitor and check the quality then dispose those that do not match up TQM requires the entire company and employees to help maintain the reasonable levels that management wants (Jafar, Mohammad, Fariba, \& Mehrdad, 2010). TQM has several goals that companies could achieve. One is to have a never ending push to improve the product or the service, the second is to require all personnel's involvement and the third, is the most important, is customer satisfaction (Stevenson, 2009, p. 427). TQM has a more to do in a company then just improve the quality of a product. When a company begins to enact a TQM program, the process becomes fluid and in this innovation is a by-product of higher quality. In the modern business world innovation is just as important as quality so they must go hand and hand and one complements each other (Perdomo-Ortiz, Gonza' lezBenito, \& Galende, 2009, p. 5088).

\subsection{Total Quality Management for both Private and Public Sectors}

In the 1980s TQM was designed for the private sector as way to grow and reduce costs of have been conducted to see if a practice in TQM could or would help companies to improve the quality of the products (BUKLYTÉ \& RUŽEVIČIUS, 2010, p. 55). When studies indicated that improvements had been found, the public sector started looking into if this was possible for the government to improve on policies that had already been made. 
For example the Korean government looked in to implementing some TQM in 43 of its agencies. By enacting these changes the Prime Minister of South Korea noticed that the government saw a reduction of bottlenecks in all forms of business conducted by the Korean government. The policies seemed to work better for the people and the overall government seemed to flow much smoother (Hur, 2009, p. 848). In Sweden the change allowed policy makers to base decisions on fact of what the people needed. The Swedish people also seen that they had a greater voice in what was being done with their country and policies that had and were being passed (Bergvall-Ka ${ }^{\circ}$ reborn, Bergquist, \& Klefsjo“, 2009, pp. 1377-1378).

\subsection{Total Quality Management as a Strategy}

Companies that grasp the TQM idea have to make it a strategic decision. In most companies that are established, they need to change the entire structure to reflect the TQM idea of constantly improving the products or the services that the company is offering. If the company is a new start up, the CEO and board must then look at the TQM while the mission statement and vision of the company are taking shape (Brown, 2011, p. 341). Google is a strong example of this kind of thinking starting from the ground up with TQM in the company's frame work. Google is known for their decentralized organization that many companies have tried to follow. By using TQM Google has created a work environment that its employees love to work in (Colquitt, Lepine, \& Wesson, 2009, p. 66).

There are a few ideas that managers need to remember when looking at TQM. First, TQM is a system that needs to be followed. Once the direction is developed the system needs to be kept in order for success to be made. The next is that the system has a set of values and practices that must be followed for success. The last one is that goals are directed towards internal and external satisfaction. The internal satisfaction is within the company dealing with employee involvement and the external is outside the company dealing with customer loyalty. An organization that adopts a TQM program is looked at by both the customer and the employee as an open organization which is completely on track with continuously improving the company, the product, and or service. This kind of public relations is good for the company, but in some cases this can indicate a decentralized organization (BUKLYTÉ \& RUŽEVIČIUS, 2010, pp. 58-59). With a decentralized organization information is allowed to flow more effetely between customers to employees then to management.

Some of the characteristics of TQM are: TQM is organization wide, the CEO must give his or her complete support, Total Quality Management is ingrained value in the entire company, partnership with both suppliers and customers alike, there is a reduction of cycle time from products, and a company who must do it right the first time (Brown, 2011, p. 346). TQM must be an organization wide policy; if it is not, different parts of the company can show weakness in both areas moral and quality of the product. Increased moral is an inherent side effect of TQM. As stated before with increased employee involvement and a noticeable decentralization of the organization, there is a very good effect on the moral of the workers. This can work in the same effect as Elton Mayo's experiment with the 
Western Electric plant in Hawthorne, IL. The workers improved productivity no matter what setting the lights were on, workers were just happy that management thought of them.

For TQM to work the company must have quality running through its veins. For a company that decides to move toward the Total Quality side managers must be willing to go the full distance. Stating that a company is after quality but never actively perusing it will no doubt show in the final product and the cost of implementing the program will outweigh the benefits of taking on this amount of change.

A company with TQM needs to work with suppliers and the customers. One of WalMart's major advantages in the retail industry is its supply chain process. Wal-Mart has a very close working relationship with its suppliers which allows it to gain access to merchandise far quicker than its competitors do. This is the same concept that a company that is implementing TQM must be able to work toward as well. A close relationship with suppliers can allow the company to have higher quality raw materials at a discounted rate and faster shipping. A manager who is actively part of company that is involved in TQM will see that all areas under his or her control are set up to add increase to the company's bottom line. Just in the same way that a company must have close relationship with the supplier, a company must have a good relationship with the customer. Without customers the company doesn't need to have any relationship with a supplier because products are not being sold and services are not being provided. A company that has a solid relationship with the customer base listens to the customer and find out what the customer is looking for and what the complaints are toward the company. Just in the same way that the Swedish people were happy because they had an active role with the government, customers can be satisfied with a company that allow them a voice.

Another byproduct of the TQM system is reduced cycle time. When a company has improved it quality system to an art, the time that it takes for products to be produced or services to be completed is greatly reduced. As employee commitment become higher the work that he or she does becomes better and faster. When a company begins looking at quality, they discover that employees could be shifted to other jobs and duties that he or she may be better suited for thus creating what Adam Smith saw as a complete division of labor. This division is where the person with the best skills for a task is positioned in the job he or she is more effective in (Smith, 2010, p. 13). By using division of labor, cycle time is reduced and employees are more satisfied.

When a company is undertaking TQM, a company must do it right the first time for a stronger and more cost effective product. The company must not wait until the very end of the production to see that the quality is bad. This needs to be done once the poor quality is discovered and disposed of then. A product must pass an inspection at the end of each stage. This is one of the major areas in which employee involvement is critical because management then on the watchful and experienced eye of the front line worker. Sun Tzu said that the man on the spot is the best judge of the situation (Michaelson \& Michaelson, 2010, p. 77) . The manager must trust in the line worker that he or she can spot the problem early before wasting the money and production time working on a defective product. 
3. The Global Market

The world is a global market place; companies no longer have to just compete against the store or factory across the street or the country but also across the world. With air travel and the invention of the Internet, the world has become very small. Companies have to take in account global competition to survive to the next quarter and be innovative to the point of redundancy to obtain and create the sustainable competitive advantage (Surendran, 2010). It is in this competitive advantage that the company begins to set itself apart from the other major companies in the world. General Motors (GM) ran in to the global village face first. GM was one of the largest auto manufactures in the world for much of the company's life until the Japanese adopted the idea of TQM in their model. The Japanese have done extremely well with this concept with evidence showing from Toyota. GM went in a few years from the largest automaker to second behind Toyota, the Japanese company that had little success in the United States (Jafar, Mohammad, Fariba, \& Mehrdad, 2010, p. 20). The quality of GM stayed the same while Toyota had increased quality thus creating a void from GM. Once consumers began to believe that Toyota built the better car, GM has been trying to play catch up. According to JD Power and associates, GM and Toyota have the exact same initial quality ratings (JD Power and Associates, 2011). The problem here is the perceived quality that the buyer believes their getting a better car thus giving Toyota the largest automaker in sales of 2010 at 8.42 million versus GM's 8.39 million (RAMSEY, 2011). Perceived quality became the difference Toyota up to the top spot.

\section{Costs of Total Quality Management}

When a company starts using TQM and using it effectively, cost are sure to come down. The cost of a product or service can be broken down into four regions: 1) prevention costs, 2) appraisal costs, 3) internal costs, and 4) external cost. Prevention costs consist of the cost incurred by the company to create and maintain the new quality system. The appraisal costs include inspecting and the test materials that are required to constantly check and maintain the quality of both the product and service. Internal failure is the cost incurred by the company if the product doesn't meet the new quality standards. The final major cost to the company is the external which are products that have been produced, sold, and then returned back with defects (Jafar, Mohammad, Fariba, \& Mehrdad, 2010, pp. 19,20). The company has the opportunity to save money in all of the areas that result in a product either being thrown out at the manufacture or being returned to with defects. Massive amounts of returns can hurt a company's image and ultimately sales. Industries that have either a low cost for new entries or have a large competitive market could have the largest problems with defective items. The customer could easily move to a competitor or a new company could see the potential demand whole not being filled and take the market with a better product (Surendran, 2010, p. 57). The old saying that competition is good still hold true. Industries with little to no competition have virtually no other forces to make the product better. This is not only bad for the consumer but this can also hurt the company down the road. Therefore by constantly checking for quality a company reduces waste and lowers costs. 
5. Conclusion

Total Quality Management is just what the name suggests, a total look at the quality of the organization. This is requires the oversight of managers and CEO's who implement the change. The workers of the organization must be in with full commitment to the organization, the product or service that is being provided. The stakes are higher for companies now because of the global marketplace. That has evolved due to the fact that companies are not just competing local or nationally are forced in competing on a globally. The company needs to know that taking the TQM system in the organization requires full commitment from even the $\mathrm{CEO}$ and massive change in part of older organizations. The cost of this can be great but if the vision of the CEO is strong and the leadership is there, this vision can trickle its way down the even the lower line workers to help the transition and secure the success in completing the great task. If a company is able to completely submit itself to the TQM system profits, will increase as well as employee and customer loyalty.

\section{References}

Bateman, T., \& Snell, S. (2007). Management Leading \& collaborating in a competive world. New York City: Mcgraw-Hill Irwin.

Bergvall-Ka ${ }^{\circ}$ reborn, B., Bergquist, B., \& Klefsjo“, B. (2009). Creating social change in a municipality using a Total Quality Management approach. Total Quality Management, 1375-1393.

Brown, D. R. (2011). Experientail Approach to ORganization Development. Upper Saddle River: Pearson.

BUKLYTÉ, S., \& RUŽEVIČIUS, J. (2010). Total quality management impact on Lithuanian companies' performance efficiency. Management of Organizations: Systematic Research, 55-70.

Colquitt, J. A., Lepine, J. A., \& Wesson, M. J. (2009). Organizational Behavior. New York City: McGraw-Hill.

Decenzo, D. A., Robbins, S. P., \& Verhulst, S. L. (2010). Fundamentals of Human Resource Management. Danvers: Wileyplus.

Hur, M. H. (2009). The influence of total quality management practices on the transformation of how organisations work. Total Quality Management, 847-861.

Jafar, A., Mohammad, T., Fariba, E., \& Mehrdad, G. C. (2010). Effect of the Quality Costing System on Implementation and Execution of Optimum Total Quality Management. International Journal of Business and Management, 19-26.

JD Power and Associates. (2011). 2010 Initial Quality Study. Retrieved June 12, 2011, from jdpower.com: http://www.jdpower.com/autos/ratings/quality-ratings-by-brand/

Michaelson, G. A., \& Michaelson, S. (2010). The Art of War for Managers. Avon: Adams Media. 
P, S. K., \& Srinivasan, R. (2010). Total Quality Management and Innovation Performance: An Empirical. South Asian Journal of Management, 8-22.

Perdomo-Ortiz, J. s., Gonza' lez-Benito, J., \& Galende, J. s. (2009). The intervening effect of business innovation capability on. International Journal of Production Research, 50875107.

RAMSEY, M. (2011, January 28). Nissan Tops Honda in Sales. Retrieved January 28, 2011, from The Wall Street Journal: http://online.wsj.com/article/SB10001424052748703956604576110314253850404.html? KEYWORDS= $=$ toyota + worlds +

Smith, A. (2010). The Wealth of Nations. London: Capstone Publishing Ltd.

Stevenson, W. J. (2009). Operations Management. New York City: McGraw-Hill Irwin.

Surendran, S. (2010). Strategic Management. New York City: McGraw-Hill. 